Agricultural Journal 6(6): 347-352, 2011

ISSN: $1816-9155$

(C) Medwell Journals, 2011

\title{
Response of Tobacco Cultivars to Varying Fertiliser Levels in Striga gesnerioides Infested Soils in Zimbabwe
}

\author{
${ }^{1} \mathrm{C}$. Koga, ${ }^{2} \mathrm{E}$. Mwenje and ${ }^{1} \mathrm{D}$. Garwe \\ ${ }^{1}$ Tobacco Research Board, Box 1909, Harare, Zimbabwe \\ ${ }^{2}$ Bindura University of Science Education, P. BAG 1020, Bindura, Zimbabwe
}

\begin{abstract}
The effect of varying fertiliser levels on the response of five tobacco (Nicotiana tabacum) varieties to Striga gesnerioides infestation was studied for three seasons at a $S$. gesnerioides-infested site. A split-plot design with cultivar as main plot factor and three rates of basal fertiliser $\left(0,800,1000 \mathrm{~kg} \mathrm{ha}^{-1}\right)$ and three top dressing nitrogen fertiliser rates $\left(0,25,50 \mathrm{~kg} \mathrm{~N} \mathrm{ha}^{-1}\right)$ were investigated. Standard tobacco cultural practices were followed. Striga emergence counts were carried out at 3rd week intervals from 9 Weeks After tobacco Planting (WAP). Tobacco infestation by $S$. gesnerioides and tobacco yield were also assessed. Striga emergence was first noted at $12 \mathrm{WAP}$. Plots with high rates of nitrogen had fewer emerging and maturing Striga plants. Of the five tobacco varieties tested, T66 was the most tolerant to Striga infestation and two landraces, LR11 and 12 were the most susceptible. Yields of the landraces were significantly lower $(\mathrm{p}<0.05)$ than T66. There was a significant reduction in tobacco yield loss due to $S$. gesnerioides infestation when the variety T66 was grown at recommended basal rate $\left(500 \mathrm{~kg} \mathrm{ha}^{-1}\right)$ combined with a higher nitrogen rate $\left(50 \mathrm{~kg} \mathrm{~N} \mathrm{ha}^{-1}\right)$.
\end{abstract}

Key words: Striga, fertiliser, infestation, variety, nitrogen, Zimbabwe

\section{INTRODUCTION}

Striga gesnerioides (family: Scrophulariaceae) is an obligate parasitic flowering plant attacking tobacco, cowpea and other wild legumes (Oswald, 2005). Striga attaches to the host root, invades the host tissues and diverts the host photosynthate for its growth. It utilises the host root system for water and mineral uptake. There is a paucity of information on the economic importance of Striga on tobacco in Zimbabwe. Although, the 1st report of S. gesnerioides on tobacco in Zimbabwe was in 1948 (Wild, 1948) no host damage was reported until 2002 in the Mvuma area of the country. S. gesnerioides was confined to tobacco, posing a major threat to continued tobacco production in the area (Koga et al., 2011). Striga causes up to $75 \%$ of its overall damage to the host during its underground stage of development. Control strategies targeted at controlling emerged Striga plants, therefore do not result in increased crop yield (Berner and Winslow, 1997). In other crops, control of Striga sp., infestation includes suicidal germination with trap crops, catch cropping, application of high rates of nitrogen fertiliser and the use of organic matter and resistant varieties (Kachelriess et al., 2001; Ahonsi et al., 2002). Declining soil fertility contributes to increased Striga infestation. Striga has been used as an indicator of the nutritional status of the May 28, 2011 soil (Mbwaga, 2002). The control of $S$. gesnerioides through application of nitrogenous fertilisers and organic matter amendments has been studied often with varying and contradictory results from different geographic locations (Ahonsi et al., 2002). Control through the application of optimal levels of nitrogen and the use of resistant varieties has been successful in studies by Akademiai. Optimal nitrogen caused a reduction in number of emerged and maturing Striga plants, resulting in less seed being produced (Kachelriess et al., 2001). The severity of Striga infestation is also dependant on the amount of germination stimulants produced by different crop varieties (Haussmann et al., 2000) as evidenced by their different tolerance levels.

The selection of tolerant varieties and varieties with reduced capacity to induce the production of the germination stimulant can be a management intervention because there is a positive correlation between the amount of stimulant produced and the susceptibility to Striga infestation (Johnson et al., 2000). The present study investigated Striga biology and management in tobacco production in Zimbabwe, specifically the interrelationships between tobacco varieties, varying fertiliser nutrient levels and Striga infestation.

\section{MATERIALS AND METHODS}

Study site: The field trials were conducted in Mvuma $\left(19^{\circ} 16^{\prime} \mathrm{S}, 30^{\circ} 30^{\prime} \mathrm{E}\right)$, Midlands province, Zimbabwe. The

Corresponding Author: C. Koga, Tobacco Research Board, Box 1909, Harare, Zimbabwe 


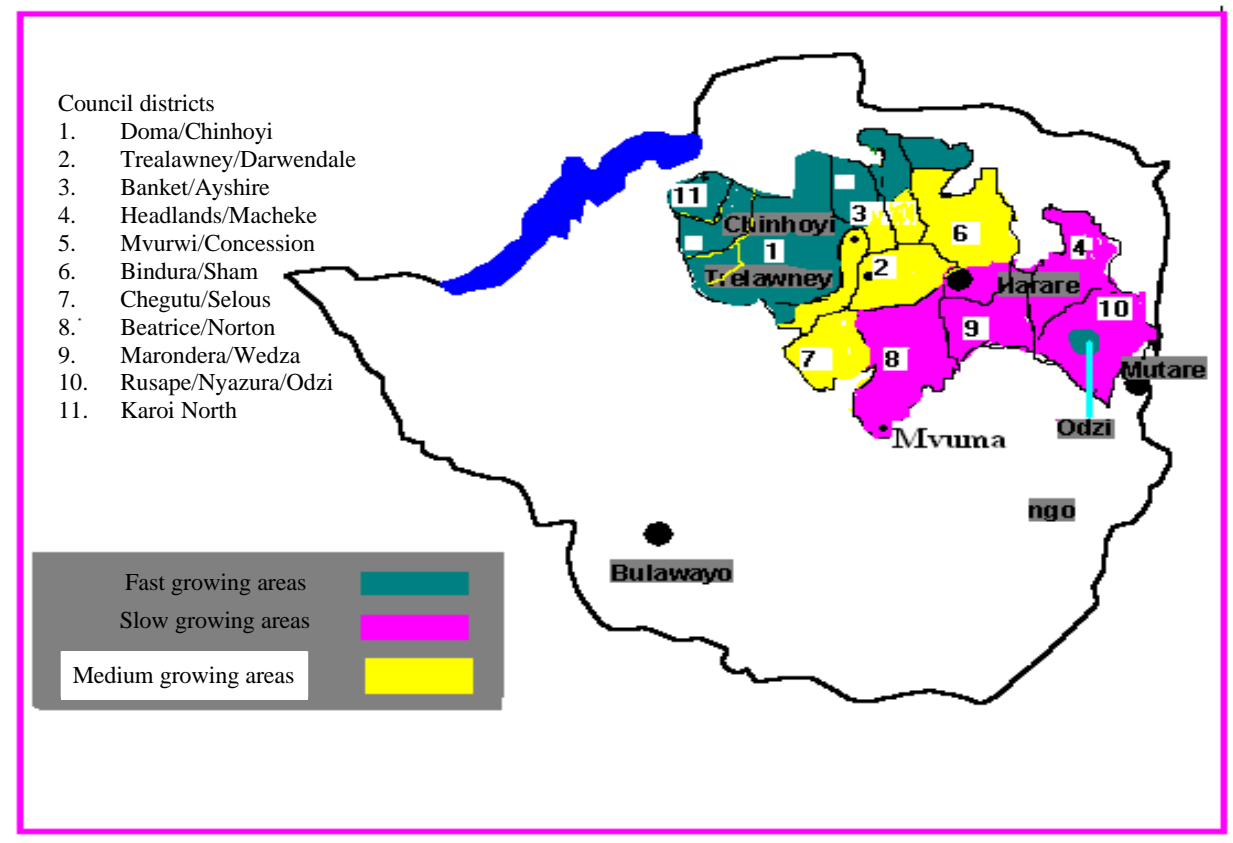

Fig. 1: Tobacco growing areas of Zimbabwe

study area has an altitude of 920-1475 m above sea level with soils of medium-heavy in texture and poorly-drained with high clay content and high water-holding capacity. Mvuma is within the slow growing area of tobacco production in Zimbabwe (Fig. 1) and receives a mean annual rainfall ranging from $650-800 \mathrm{~mm}$. Tobacco production was initiated in the area in 1997. Prior to that the area was predominantly for cattle ranching.

Field activities: The trial was established and managed following standard recommendations for tobacco production. Tobacco is grown on $20-30 \mathrm{~cm}$ ridges to avoid water logging. The plant spacing used in the study was $1.2 \times 0.56 \mathrm{~m}$. Soil samples were taken from the field for chemical analysis and fertiliser recommendations according to the method of Juo (1981). Differing levels of nitrogen, phosphorus and potassium were applied according to treatment specifications. A split-split plot design with cultivar as the main plot and fertiliser rates as the sub-plot was used in the study. There were three ammonium nitrate levels $\left(0 \mathrm{~kg} \mathrm{Nha}^{-1}\right)$, recommended rate $\left(25 \mathrm{~kg} \mathrm{~N} \mathrm{ha}^{-1}\right)$ and higher rate $\left(50 \mathrm{~kg} \mathrm{~N} \mathrm{ha}^{-1}\right)$. Basal fertiliser (Tobacco-fert, 6:15:12) rates were applied at $0 \mathrm{~kg} \mathrm{ha}^{-1}$, recommended rate $\left(800 \mathrm{~kg} \mathrm{ha}^{-1}\right)$ and higher rate $\left(1000 \mathrm{~kg} \mathrm{ha}^{-1}\right)$.

Measurements of Striga haustorium and emergence counts were taken at 9,12,15 and 18 Weeks After Planting (WAP). After 18 weeks, the tobacco crop had completed its life cycle and assessments were terminated. In Zimbabwe, tobacco is harvested at 2 leaves week ${ }^{-1}$ and cured leaf mass was determined at each reaping. Three commercial cultivars: KRK 26 [RW Parentage]; T61 [KM10 Parentage]; T66 [XM Parentage] and two land races (Landrace $11 ; 12$ ) were evaluated in the Striga-infested fields. The data were analysed using GenStat Release $7.2 \mathrm{DE}$.

\section{RESULTS}

Soil test: The $\mathrm{pH}$ of the soils $(\mathrm{pH} 5.12-5.68)$ and Electrical Conductivity (EC) were within acceptable levels $\left(<1500 \mu \mathrm{S} \mathrm{cm}^{-1}\right)$ for tobacco production and other nutrient levels were in ranges normally acceptable for tobacco production (Table 1).

Tobacco yield response to increased nutrient levels under Striga infestation: Increased fertiliser rates (both basal and nitrogen levels) significantly increased tobacco yield $(\mathrm{p}<0.05)$. The variety T66 had the highest mean yield of 2, $467 \mathrm{~kg} \mathrm{ha}^{-1}$ (Fig. 2) compared to 564 and $662 \mathrm{~kg} \mathrm{ha}^{-1}$ obtained from the two landraces (LR11 and 12, respectively).

The most common variety grown in the Mvuma area (KRK26) had a mean yield of $2,048 \mathrm{~kg} \mathrm{ha}^{-1}$. Significant differences $(\mathrm{p}<0.05)$ were noted among the basal fertiliser levels, nitrogen levels, cultivars, the interaction of basal 
Agric.J., 6 (6): 347-352, 2011

Table 1: Soilan aly sis results of Mvuma soils

\begin{tabular}{|c|c|c|c|c|c|c|c|c|c|c|c|c|}
\hline \multirow[b]{2}{*}{ Block } & \multirow[b]{2}{*}{$\mathrm{pH}\left(\mathrm{CaCl}_{2}\right)$} & \multirow{2}{*}{\begin{tabular}{l}
$\left(\mu \mathrm{S} \mathrm{cm}^{-1}\right)$ \\
\hdashline $\mathrm{EC}$
\end{tabular}} & \multicolumn{4}{|c|}{ Results (meq/100 g) } & \multicolumn{6}{|c|}{ Results $\left(\mu \mathrm{g} \mathrm{g}^{-1}\right)$} \\
\hline & & & $\mathrm{Ca}$ & $\mathrm{Mg}$ & $\mathrm{Na}$ & $\mathrm{K}$ & $\operatorname{MinN}$ & $\mathrm{P}$ & $\mathrm{Mn}$ & $\mathrm{Zn}$ & $\mathrm{Cu}$ & $\mathrm{Fe}$ \\
\hline 1 & 5.12 & 33 & 9.78 & 10.85 & 0.05 & 0.51 & 40 & 2 & 402 & 2 & 13 & 275 \\
\hline 2 & 5.68 & 46 & 18.46 & 21.66 & 0.08 & 0.47 & 70 & $<1$ & 539 & 2 & 10 & 177 \\
\hline 3 & 5.39 & 22 & 7.09 & 8.56 & 0.05 & 0.37 & 40 & $<1$ & 195 & 2 & 6 & 249 \\
\hline 4 & 5.52 & 26 & 2.15 & 0.53 & 0.03 & 0.33 & 40 & 38 & 42 & 5 & 2 & 77 \\
\hline 5 & 5.42 & 34 & 13.62 & 13.96 & 0.08 & 0.36 & 30 & $<1$ & 382 & 2 & 11 & 233 \\
\hline
\end{tabular}

Table 2: Statistical data on cultivar mean yield with different basal and nitrogen fertiliser levels

\begin{tabular}{|c|c|c|c|c|c|}
\hline \multirow[b]{2}{*}{ Fertilisers } & \multicolumn{3}{|c|}{$\begin{array}{l}\text { Means with different levels } \\
\text { of cultivar }\end{array}$} & \multicolumn{2}{|c|}{$\begin{array}{l}\text { Means with same } \\
\text { levels of cultivar }\end{array}$} \\
\hline & F-prob & SED & LSD & SED & LSD \\
\hline Cultivar (C) & $<0.001$ & 232.00 & 505.40 & - & - \\
\hline Basal (B) & $<0.001$ & 84.20 & 172.00 & - & - \\
\hline Nitrogen $(\mathbb{N})$ & $<0.001$ & 38.80 & 77.00 & - & \\
\hline $\mathrm{C} \times \mathrm{B}$ & $<0.001$ & 278.30 & 575.60 & 188.30 & 384.60 \\
\hline $\mathrm{C} \times \mathrm{N}$ & 0.013 & 242.50 & 519.00 & 86.70 & 172.20 \\
\hline $\mathrm{B} \times \mathrm{N}$ & $<0.001$ & 100.50 & 201.20 & - & - \\
\hline $\mathrm{C} \times \mathrm{B} \times \mathrm{N}$ & 0.846 & 304.10 & 619.00 & 224.70 & 449.90 \\
\hline
\end{tabular}

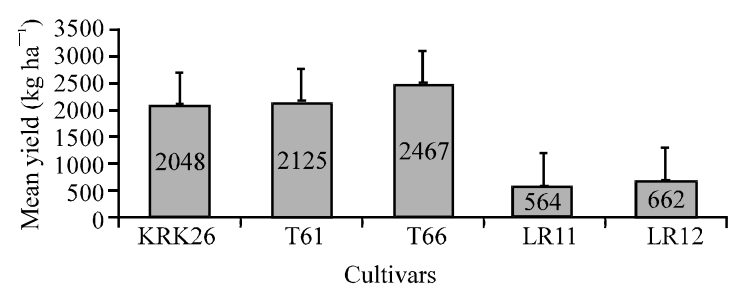

Fig. 2: Tobacco yield per cultivar at combined basal and nitrogen fertiliser levels

and nitrogen, basal and cultivar, nitrogen and cultivar but there was no overall significant interaction ( $\mathrm{p}>05$ ) among basal, nitrogen and cultivar (Table 2).

Tolerance and susceptibility of different cultivars in Striga-infested soils: The cultivars exhibited visual differences for Striga damage symptoms, especially with the two landraces (LR11 and 12) succumbing more to Striga than the other cultivars (T61, T66 and KRK26). At 12 and $15 \mathrm{WAP}$, no damage to the tobacco crop was observed but at $18 \mathrm{WAP}$, the two land races (LR11 and 12) had up to $50 \%$ leaf damage as a result of the effects of the parasitic weed.

The other varieties still had no symptoms of Striga leaf damage at 18 WAP. Figure 3-8 shows $20 \mathrm{WAP}$ and the two land races (LR11 and 12) had close to $100 \%$ leaf damage whilst the other varieties (KRK26, T61 and 66) had moderate levels of leaf damage.

Effect of basal fertilizer rates on Striga emergence counts: There were no significant differences in Striga counts at various basal fertiliser rates and the interaction

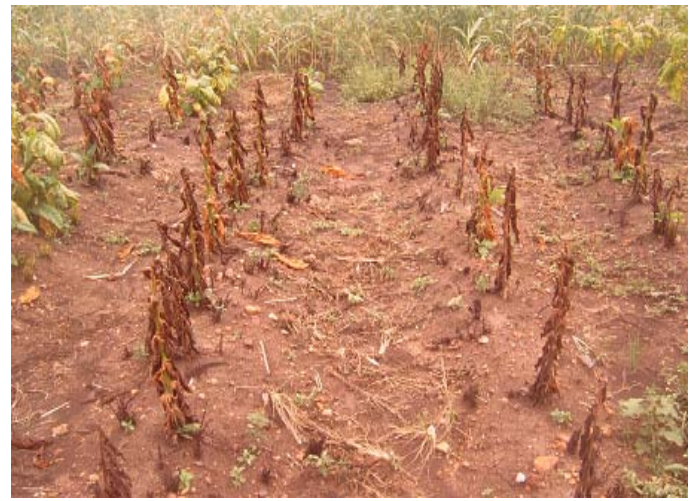

Fig. 3: LR12 severely infested

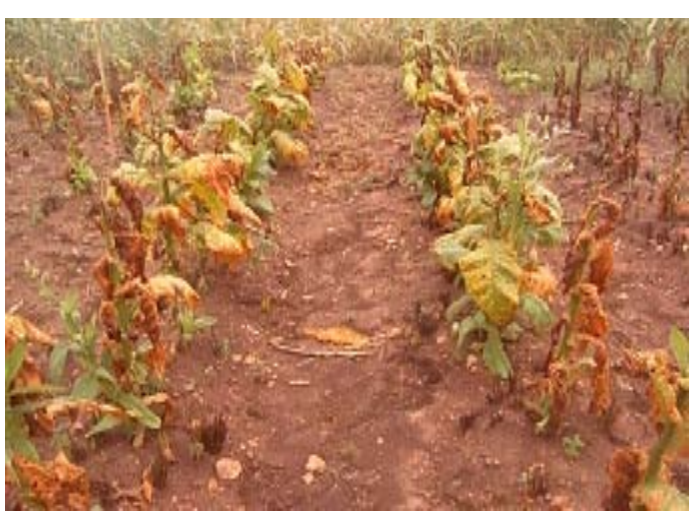

Fig. 4: LR11 severely infested

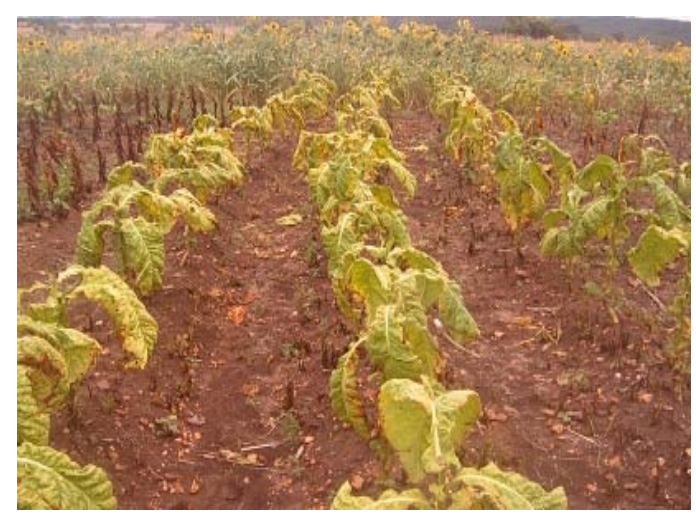

Fig. 5: KRK26 showing some tolerance 
Agric. J., 6 (6): 347-352, 2011

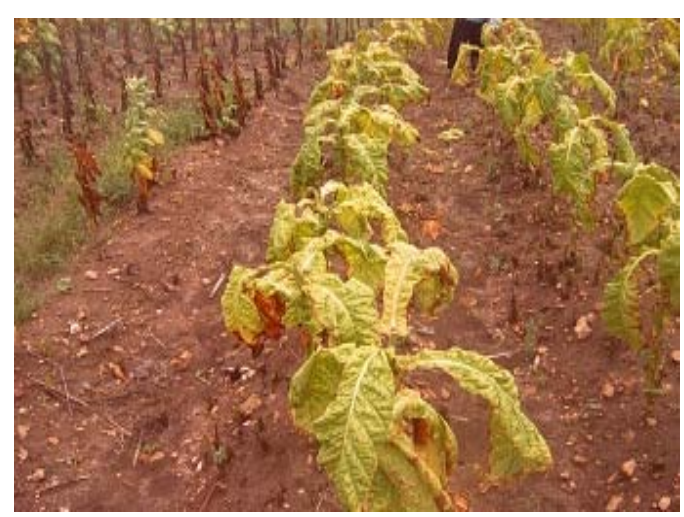

Fig. 6: T61 moderately infested

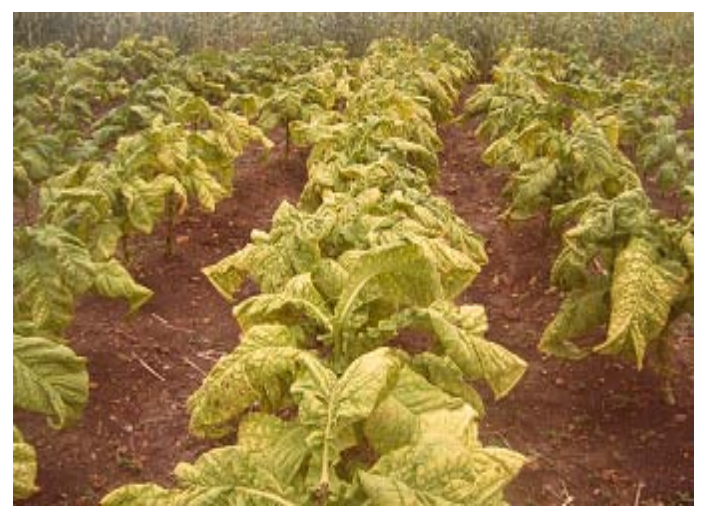

Fig. 7: T61 showing high tolerance

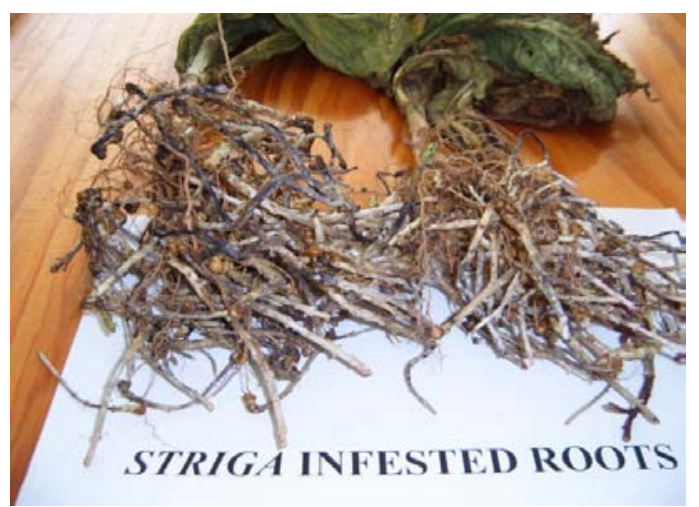

Fig. 8: Striga infested tobacco roots

between cultivar and basal fertiliser levels was also not significant $(p>0.05)$. The trend was similar at all the assessment times (12, 15 and $18 \mathrm{WAP}$ ). In most cases, higher Striga counts were recorded in high basal fertiliser treatments. Figure 9 shows the mean Striga counts per cultivar with increased basal fertiliser rates. Generally, T66 had fewer Striga plants emerging compared to all cultivars, although not statistically different.

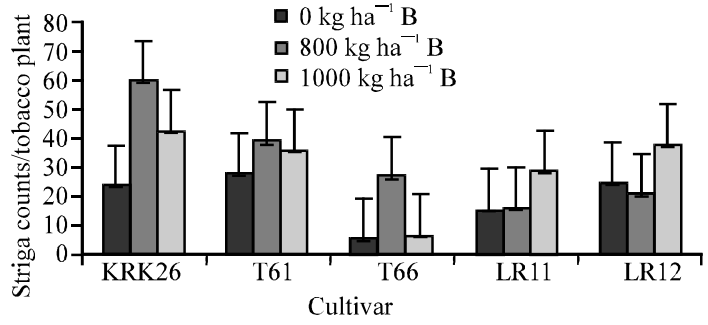

Fig. 9: Effect of basal fertiliser levels on Striga counts per cultivar $(18 \mathrm{WAP})(\mathrm{LSD}=13.2, \mathrm{~F}$. prob. $=0.12)$

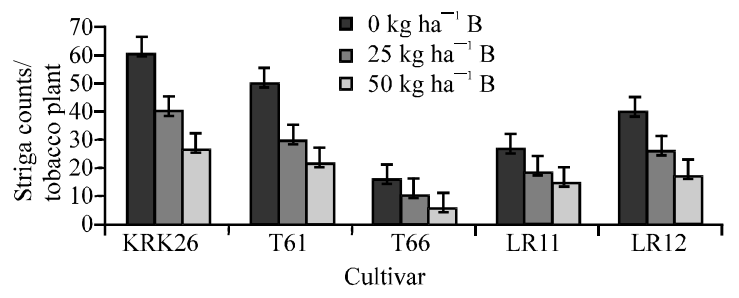

Fig. 10: Effect of nitrogen fertiliser levels on Striga counts (18 WAP) $(\mathrm{LSD}=5.56, \mathrm{~F}$. prob. $<0.01)$

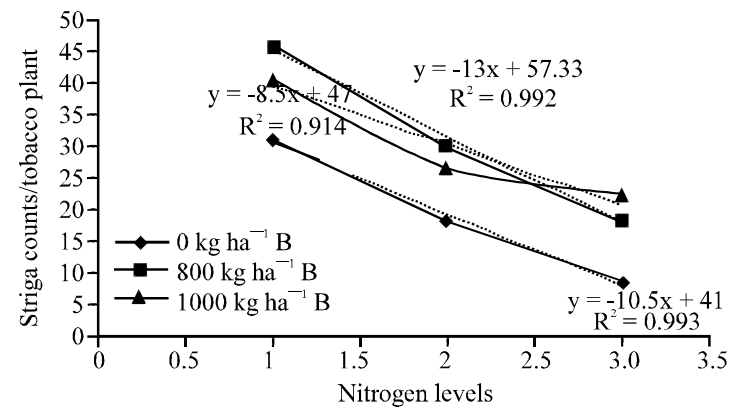

Fig. 11: Nitrogen effect on Striga counts

Effect of Nitrogen fertilizer rates on Striga emergence counts: There were significant differences in Striga counts among nitrogen rates $(p<0.05)$. Increasing nitrogen levels from $0-50 \mathrm{~kg} \mathrm{~N} \mathrm{ha}^{-1}$ resulted in significant $(\mathrm{p}<0.05)$ reduction in Striga emergence counts across all the varieties (Fig. 10). Generally, the number of emerged Striga counts increased between 12 and 18 WAP. At 18 WAP, the variety KRK26 was heavily infested with 60 parasitic weeds recorded in non-fertilised plots compared to 5 Striga plants in T66 plots with $50 \mathrm{~kg} \mathrm{~N} \mathrm{ha}^{-1}$. Generally, T66 variety had the least Striga counts recorded from the onset of assessments and the counts were low in all the three nitrogen fertiliser levels.

Nitrogen levels and Striga counts: A regression analysis to determine the relationship between nitrogen fertiliser rates and Striga counts showed a very strong relationship (Fig. 11). A more linear relationship in Striga counts 
was found in plots where increased nitrogen levels $\left(0-50 \mathrm{~kg} \mathrm{~N} \mathrm{ha}{ }^{-1}\right)$ were applied to plants with no basal fertiliser with the $R^{2}$ value of the best-fitted joint regression equations of 0.993 . However, the trend was similar among all the cultivars and at all assessment times with increased nitrogen rates resulting in reduced Striga counts (Fig. 11).

\section{DISCUSSION}

Previous research by Osman et al. (1991) showed that nitrogen did not reduce Striga incidence but neutralised the harmful effects of the parasite. However, severity of infestation showed that the Striga is negatively correlated with soil fertility (Ahonsi et al., 2002; Parker and Riches, 1993; Louise et al., 2001). The results of the present study corroborate these findings. The mechanisms by which high nitrogen levels suppress Striga have not been fully established (Avav et al., 2009; Kureh et al., 2003; Adagba et al., 2002). In some studies, Striga-tolerant genotypes permitted and supported as many Striga plants as susceptible genotypes but did not show a concomitant reduction in grain production or overall productivity (Hess and Ejeta, 1992). The differential susceptibility of studied tobacco genotypes to Striga infestation presents an opportunity to screen more material for tolerance to $S$. gesnerioides. In this study, a yield loss of close to $100 \%$ in the two landraces LR1 1 and 12 with the minimum damage observed in the commercial cultivars KRK26, T66 and 61 could be a result of different cultivar tolerance levels to Striga infestation. Local landraces were often described as having tolerance to Striga (Hess and Haussmann, 1999) but in terms of stimulant production, no differences were noted among different cultivars in laboratory studies (Koga et al., 2011). However, the moderate level of tolerance exhibited by landraces was found not to provide protection at higher levels of infestation (Haussmann et al., 2000). Local landraces have been found to behave similarly to susceptible cultivars at high infestation levels supporting more Striga and allowing more parasitic plants to set seed further enriching the soil seed bank (Kling et al., 2000). Where the Striga infestation is high, only cultivars with high levels of Striga resistance would provide protection from infestation and help diminish the seed bank. If a susceptible host is frequently cultivated, the seed bank in the soil increases and continuous cropping of this host crop becomes more uneconomical (Kroschel, 2001). Crop and varietal differences to infestation by Striga species (Hess and Haussmann, 1999; Koga et al., 2011) have led to the initiation of breeding programmes for resistance. Research has shown that Striga control requires an integrated approach (Berner and Winslow, 1997; Mohammed et al., 2001), probably because of the genetic plasticity of Striga.

\section{CONCLUSION}

To ensure the continued tobacco production in Mvuma, Zimbabwe, a combination of a tolerant variety such as T66 and higher nitrogen application rates may be recommended. In this study however, the effect of basal fertiliser was not apparent as in other studies, perhaps because of the inherent soil fertility in studied soils. Further investigations could be initiated using different soil types.

\section{ACKNOWLEDGEMENTS}

The Tobacco Research Board supported and funded the study. Thanks are due to the Mvuma growers for allowing use of their fields for the study. Researchers thank Anxious J. Masuka for comments on the draft.

\section{REFERENCES}

Adagba, M.A., S.T.O. Lagoke and E.D. Imolehin, 2002. Nitrogen effect on the incidence of Strigahermonthica (Del.) Benth in upland rice. J. Acta Agron. Hungarica, 50: 145-150.

Ahonsi, M.O., D.K. Berner, A.M. Emechebe and S.T. Lagoke, 2002. Effects of soil pasteurisation and soil N status on severity of Striga hermonthica (Del.) Benth. in maize. Soil Biol. Biochem., 34: 1675-1681.

Avav, T., P.A. Shave, E.I. Magani and R.I. Ahom, 2009. Effects of Mucuna biomass and N-fertilizer on Striga hermonthica Del. Benth. infestation in maiz (Zea mays L.). J. Anim. Plant Sci., 4: 320-328.

Berner, D.K and A.E Winslow, 1997. Striga Research Methods: A Manual. 2nd Edn., International Institute of Tropical Agriculture, Ibadan, Nigeria.

Haussmann, B.I.G., D.E. Hess, H.G. Welz and H.H. Geiger, 2000. Improved methodologies for breeding Strigaresistant sorghums. Field Crops Res., 66: 195-211.

Hess, D.E. and B.I.G. Haussmann, 1999. Status Quo of Striga control: Prevention, Mechanical and Biological Control Methods and Host Plant Resistance. In: Advances in Parasitic Weed Control at On-Farm Level, Kroschel, J., H. Mercer-Quarshie and J. Sauerborn (Eds.) Vol. I, Margraf Verlag, Weikersheim, Germany, pp: 75-87.

Hess, D.E. and G. Ejeta, 1992. Inheritance of resistance to Striga in sorghum genotype SRN39. Plant Breeding, 109: 233-241. 
Johnson, D.E., C.R. Riches, M.P. Jones and R. Kent, 2000. The potential for host resistance to Striga on rice in West Africa. Proceedings of the Workshop on Breeding for Striga Resistance in Cereals, (BSRC'00), Margraf Verlag, Weilkersheim, Germany, pp: 139-145.

Juo, A.S.R., 1981. Automated and Semi-automated Methods for Soil and Plant Analysis, Manual Series No. 7. International Institute of Tropical Agriculture, Ibadan, Nigeria.

Kachelriess, S., K. Hummler and P. Fisher, 2001. Extension Aids. In: A Technical Manual for Parasitic Weed Research and Extension. Kroschel, J. (Ed.). Kluwer Academic Publisher, The Netherlands, pp: 169-179.

Kling, J.G., J.M. Fajemisin, B. Badu-Apraku, A. Diallo, A. Menkir and A. Melake-Berhan, 2000. Striga resistance breeding in maize. Proceedings of the Workshop on Breeding for Striga Resistance in Cereals, (BSRC'00), Margraf Verlag, Weilkersheim, Germany, pp: 103-118.

Koga, C., E. Mwenje and D. Garwe, 2011. Germ nat on st mulat on of Striga gesnerioides seeds from tobacco plantat ons by hosts and non-hosts. J. Applied Biosci., 37: 2453-2459.

Kroschel, J., 2001. A Technical Manual for Parasitic Weed Research and Extension. Kluwer Academic Publishers, Dordrecht, The Netherlands, pp: 256.

Kureh, I., D. Chikoye, A.M. Emechebe, M.A, Hussaini and P. Kormawa et al., 2003. Reduction of Striga hermonthica parasitism on maize using host plant resistance, $\mathrm{n}$ fertilization and rotation with legume trap-crops. Afr. Crop Sci. Conf. Proc., 6: 167-171.
Louise, A., D.G. Bernard and Y. Sanhouin, 2001. Integrated control of Striga in farmers maize fields. Proceedings of the 7 th International Parasitic Weed Symposium, June 5-8, Nantes, France, pp: 302-302.

Mbwaga, A.M., 2002. Strategies for transfer of Striga control technologies to African farmers: A case study for Tanzania. Proceedings of the 4th General Workshop of Pan-African Striga Control Network, Oct. 28- Nov 1, 1996, Bamako, Mali, pp: 38-41.

Mohammed, A., P. Rich, T.L. Housley and G. Ejeta, 2001. In vitro techniques for studying mechanisms of Striga resistance in sorghum. Proceedings of the 7 th International Parasitic Weed Symposium, June 5-8, Nantes, France, pp: 96-101.

Osman, M.A., P.S. Raju and J.M. Peacock, 1991. The effect of soil temperature, moisture and nitrogen on Striga asiatica (L.) Kuntze seed germination, viability and emergence on sorghum (Sorghum bicolor (L.) Moench.) roots under field conditions. Plant Soil, 131: 265-273.

Oswald, A., 2005. Striga control: Technologies and their dissemination. Crop Prot., 24: 333-342.

Parker, C. and C.R. Riches, 1993. Parasitic Weeds of the World: Biology and Control. CAB International, Wallingford, UK., ISBN: 0851988733, pp: 332.

Wild, H., 1948. A suggestion for the control of tobacco witch weed (Striga gesnerioides). Rhodesia Agric. J., 45: 208-215. 